\title{
Response to the letter: Angiotensin-II induced insulin resistance
}

\author{
Resistência à insulina induzida por angiotensina-II
}

1 Division of Medical Physiology, Department of Physiological Sciences, University of Oriente, Ciudad Bolívar, Venezuela ${ }^{2}$ Cardiology Research Institute, University Hospital of Los Andes, Mérida, Venezuela ${ }^{3}$ Endocrinology Unit, University Hospital of Los Andes, Mérida, Venezuela

Correspondence to: Marcos M. Lima-Martínez Av. Tachira, Conjunto Residencial Monacaya, Town House 12 8001 - Ciudad Bolívar, Bolívar, Venezuela

marcoslimamedical@hotmail.com

Received on Aug/11/2014 Accepted on Sept/9/2014

DOI: $10.1590 / 0004-2730000003649$
Marcos M. Lima-Martínez'1, Gabriel López-Mendez², Rodolfo Odreman², José H. Donis², Mariela Paoli ${ }^{3}$

W e have examined with attention the comments of the letter to the Editor in regards to our recently published article (1), and want to thank its authors for their interest in our work.

Indeed, it has been demonstrated that, upon acting on the ATl receptor, angiotensin II activates matrix metalloproteases that release the epidermal growth factor (EGF), binding to its receptor promotes the activation of mammalian target of rapamycin (mTOR) and ribosomal S6 kinase-1, both of which inhibit phosphatidylinositol 3-kinase insulin signaling, thus favoring insulin resistance (2-4). Interestingly, some clinical studies have demonstrated that treatment with either angiotensin I-converter enzyme inhibitors (ACEI) or angiotensin II receptor antagonist (ARA) reduces the incidence of diabetes mellitus in high risk patients $(5,6)$.

Our study compared a group of metabolic syndrome (MS) patients (31 subjects) with a control group (27 subjects), and, as pointed out in the Results section, 13 out of 31 MS patients presented high blood pressure (41.9\%), whereas none of the subjects in the control group were hypertensive $(0 \%)$, not receiving therefore hypertension medication. As mentioned in the study, 10 of the 13 patients with high blood pressure and MS were treated with monotherapy ( 6 with ACEI and 4 with ARA), and the other three were on a combined therapy of ARA with calcium antagonist (2), and ACEI with a diuretic (1). Our study found that patients with MS revealed a greater thickness of epicardial adipose tissue (EAT) $(5.69 \pm 1.12$ vs $3.52 \pm 0.80 \mathrm{~mm} ; \mathrm{p}=$ 0.0001 ) in comparison with the subjects in the control group (1). As far as we know, no study has demonstrated that ARAs or ACEIs decrease EAT thickness, and although it is described that both antihypertensives drugs reduce insulin resistance, we observed that the study group had greater basal plasma insulin concentrations than those of the control group $(6.08 \pm 5.22$ vs. $2.10 \pm 0.54 ; \mathrm{p}=0.0001)$, and even greater trigliceryde/HDL-C ratio $(4.52 \pm 2.37$ vs. $2.10 \pm 1.15 ; \mathrm{p}=0.0001)$, which is considered a surrogate marker of insulin resistance (7).

Furthermore, a larger left ventricular mass $(60.28 \pm 14.00$ vs. $53.01 \pm 8.40$; $\mathrm{p}=0,019)$ and lower adiponectin plasma levels $(11.20 \pm 2.65$ vs. $14.95 \pm 3.87 ; \mathrm{p}=$ $0,0001)$ were found in subjects with MS as compared to the control group. In agreement with the comments of the letter to the Editor, both ACEI and ARA have been shown to reduce left ventricular mass; however, it is worth noting that only subjects belonging to the MS group were receiving such therapy, whereby it can be asserted that this aspect had little incidence on the results. Furthering into the beneficial effects of ACEI and ARA, new analyses were carried out, and upon comparing the patients receiving these drugs $(n=13)$ with those MS patients receiving different medication or not receiving antihypertensives $(n=18)$, the levels of insulin $(5.37 \pm 4.03$ 
vs. $6.58 \pm 6.0 ; \mathrm{p}=0.507)$, left ventricular mass $(63.72$ $\pm 57.78 ; \mathrm{p}=0.252)$ and epicardial fat $(5.37$ vs. 5.92 ; $\mathrm{p}=0.169$ ) were not different; however, the levels of adiponectin were significantly higher in those MS patients being treated with ACEI and ARA $(12.53 \pm 2.93$ vs. $10.23 \pm 1.98 ; \mathrm{p}=0,02)$, though they continued to be lower than those subjects in the control group $(12.53 \pm 2.93$ vs. $14.95 \pm 3.87 ; \mathrm{p}=0.037)$. It is important to investigate the beneficial metabolic effects of this type of antihypertensive, using appropriate study designs. Since there were no high blood pressure subjects in our control group using hypertension medication, we consider that this possible effect of ACEI and ARA was not a limitation to achieve our objective.

Disclosure: no potential conflict of interest relevant to this article was reported.

\section{REFERENCES}

1. Lima-Martínez MM, López-Mendez G, Odreman R, Donis JH, Paoli M. Epicardial adipose tissue thickness and its association with adiponectin in metabolic syndrome patients from Mérida, Venezuela. Arq Bras Endocrinol Metab. 2014;58(4):352-61.

2. Olivares-Reyes JA, Shah BH, Hernández-Aranda J, García-Caballero A, Farshori MP, García-Sáinz JA, et al. Agonist-induced interactions between angiotensin AT1 and epidermal growth factor receptors. Mol Pharmacol. 2005;68(2):356-64.

3. Arellano-Plancarte A, Hernandez-Aranda J, Catt KJ, OlivaresReyes JA. Angiotensin-induced EGF receptor transactivation inhibits insulin signaling in $\mathrm{C} 9$ hepatic cells. Biochem Pharmacol. 2010;79(5):733-45.

4. Lima MM, Nuccio JC, Villalobos M, Torres C, Balladares N. Sistema renina angiotensina y riesgo cardiometabólico. Rev Venez Endocrinol Metab. 2010;8(1):3-10.

5. Yusuf $S$, Sleight P, Pogue J, Bosch J, Davies R, Dagenais G. Effects of an angiotensin-converting-enzyme inhibitor, ramipril, on cardiovascular events in high-risk patients. The heart outcomes prevention evaluation study investigators. $\mathrm{N}$ Engl J Med. 2000;342(3):145-53.

6. Navigator Study Group, McMurray JJ, Holman RR, Haffner SM, Bethel MA, Holzhauer B, et al. Effect of valsartan on the incidence of diabetes and cardiovascular events. $\mathrm{N}$ Engl J Med. 2010;362(16):1477-90.

7. Roa Barrios M, Arata-Bellabarba G, Valeri L, Velásquez-Maldonado $\mathrm{E}$. Relación entre el cociente triglicéridos/cHDL, índices de resistencia a la insulina y factores de riesgo cardiometabólico en mujeres con síndrome de ovario poliquístico. Endocrinol Nutr. 2009;56(2):59-65. 